\title{
Present \& Future Challenges of Lockdown in India and Abroad
}

\author{
Smt. Bharati Das*, Dr. C. Revathi ${ }^{+}$ \\ * JagadishprasadJhabermalTiberwal University, Jhunjhun, Rajasthan \\ ${ }^{+}$Manjaridevi Collage of Nursing, Bhubaneswar, Odisha
}

\begin{abstract}
Covid-19 pandemic is the world's greatest health hazard/crisis in the present scenario and the greatest challenge we have faced since World War II. It was first originated/identified in $31^{\text {st }}$ December, 2019 in Wuhan. However, a present conflict lies on the origin of the virus was from Wuhan wet-markets or the Institute of Virology, Hubei Province of China and spread to European countries and worldwide. WHO declared it as Global Pandemic and now it has spread to almost all continents causing severe spike In corona virus infected

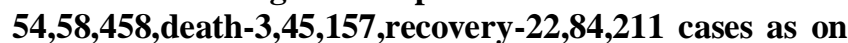
27.05.2020in 213 countries globally, which is a matter of great concern. The more countries it reached, the more it devastated the Social, Political, Economic, Agriculture, Medical aspects leaving deep scars. All countries are fighting to slow down the spread of virus by tracking, tracing, testing and treating the patients by limiting travel, curbing lockdown, registering migrant workers on line in my government portal,quarantining citizen and cancelling possible large gathering in various places. In this context, the effect of lockdown including the impact on social, political, financial, etc. aspect of societies is discussed. In addition, an attempt is made to shed light on the duties of a responsible citizens and government. Later a brief description is conveyed on what can be the future challenges for both government and citizens.
\end{abstract}

Keywords:- Pandemic, Socio-cultural challenges, migrantworkers, Hydroxychloroquine.

\section{INTRODUCTION}

"A lockdown is the most important step in breaking the virus transmission of disease and isolation is the best weapon", Director ,ICMR.The Prime Minister of India Narendra modi's announcement of a national lockdown for 21 days on $22^{\text {nd }}$ March2020 is an unprecedented decision in Indian history.Lockdown is existed throughout human history in different forms and for different reasons, either to stop a pandemic,or to fight against terrorism or technological disaster. The Janata curfew has been imposed successfully with a move to educate people on importance of curfew.People kept indoors as an inherent part of social distancing which is sure to have helped in the fight against covid-19.

Humanitarian disaster Covid-19(corona virus disease) is an infectious disease which is caused by novel corona virus.It spreads primarily through droplets of saliva or discharge from nose when an infected person coughs or sneezes. It is most contagious when the patient is symptomatic, however transmission may occur in asymptomatic patient as well. It has incubation period of 214 days in general. However a healthy person might get infected and further spread the disease to other healthy individual.

In March,2020 corona virus spread in India,when markaz event TablighiJamaat organized inNizamuddin in south Delhi from $13^{\text {th }}$ to $15^{\text {th }}$ march,2020 attended by 17000 delegates from India and Abroad.Till now the corona positive infected cases in India is 1,58,052 confirmed cases, 85,808 active cases, 67,711 recovery cases and 4534 death cases.No medicine,drug and vaccineshave been discovered for covid-19.

\section{SIGN \& SYMPTOMS}

While fever,cough and difficulty in breathing are some of the common symptoms of covid-19, the disease has also been known to different parts of the body.It is being reported that covid-19 over stimulate immune system.People above 60 years of age,young people,child teenage are also vulnerable to the disease.Old people those with underlying medical problems like cardiovascular disease,diabetes,chronic respiratory disease,cancer are more prone to develop serious illness.

In some countries like spain,USA, it is reported some cases of "covid toe"which is a skin condition characterized by purpleblue or red discoloration of toes sometimes fingers. Those children infected with covid-19 have been observed with multisystem inflammation. This rare illness causes the inflammation of blood vessel leading to low blood pressure. Also there have been cases of neurological abnormality like acute cerebrovascular disease impairedconsciousness, impairment in the sense of taste and smell.

All over the world,the only way to control and defeat the pandemic was to make people to follow social distancing and also to make themselves quarantined.So to effectively achieve this objective several countries had to brought under lockdown.Amidst of the crisis Indian Govt. also took a strong stand against the pandemic and imposed nationwide lockdown from last week of march to prevent the corona virus spread and it is currently under its fourth phase. 


\section{MAJOR DUTY OF CITIZENS AND OFFICIALS:}

In anticipation of corona vaccine,the first line of defense against the novel coronavirus is a set of simple measures that involves little expenditure,physical distancing of atleast one meter,mandatory use of face mask or cloth cover,frequent hand washing with soap,respiratory etiquette,sanitizing contact surfaces and self monitoring of health. Everybody should follow the golden principles for individual and family and community safety.Frequent training of personnel deployed in handling the patients.Sufficient testing kits should be provided for speedy scanning/identification of positive \& negative cases.Medical staff should use personal protective equipment for their safety which includes Gloves,Medical mask,Goggles, Face shield \& Gowns, Respirator and Apron.

Role of administration is very important for commanding control and to manage situations arising out of covid-19.The ministry of Health \&Home of Centre and State Governments are the nodal Departments to enforce SOP and guide lines on covid-19.The state administration has taken necessary preparedness planning,human resource development\& required steps for smooth implementation of certain measures like registration online of migrant workers coming from different states, self registration in Arogya-Setu mobile application. Also the governing bodies have taken steps on identification of migrant workers, sending them to quarantine, home-quarantine or isolation, building containment zones,restricting public health measures, environmental sanitation for smooth management $\&$ control of covid-19.

\section{Economical Challenges}

The present challenges of lockdown are many.Due to continuous lock down to 4.0 fourth stage, the economy of the Government,Public,Private,Organized\& un-organized sector ,Banking \& Non-Banking sector have been affected in a very great extent.In Bombay stock exchange (BSE), shares came down to a record low level for both Sensex and Nifty.During lockdown period Rail,Road and Air communication are in completely shutdown mode.Factory,Industry,Company,Trade

Commerce,Business, Office,Transport and Agriculture have stopped production. Workers \& employees are thrown out of their jobs.Due to non-payment of salary for long period their family are facing a lot of financial difficulties, unable to pay house rent to the owner and remaining in starvation.So the migrant workers with their family decided to return to their Native State in massive scales.As there was no rail,road \& air communication they started moving by footing,by-cycle,by motor lunch in the river,by hire vehicles,Special Train,truck etc. which was great problem for the administration to control them and keep them in quarantine.There was no any correct information of migrant workers of different states.The Central Govt.declared in march,2020that the total number of migrant workers in India is 10 crore but in 2011 census report, the migrant workers number is 45.36 crore.For their livelihood 20 crore migrant worker are going to other states.As per Govt. of India report $90 \%$ migrant workers are working un- organizing sector.From the severe hot spot zone 36 lakhs stranded migrants across the country are returning to their native village states by 2600 Shramik Special Trains within 10 days .As per last census figure more than 4 crore people migrate for work in the country, according to the joint secretary MHA.In addition to those travelling on Shramik Special more than 40 lakhs migrants had travelled on Interstate buses.

In reality, the migrants and their family members are our very best human resources. The country's prosperity \& development dependson its humanresources.In order to revive the economy,the role of human resources is very much vital.The Supreme Court of India has directed Center and all State Govt. to provide food \& shelter to each migrant to mitigate their misery \& distress condition.

\section{> Psychological Challenges}

As per report of the Health Dept.corona leads to psychological problem and depression among the migrant workers and their family members causing more than $30 \%$ domestic violence cases in police stations and women Commission.In May 182020 among 20000 migrants 1000 psychological depression cases are noticed as per report of the psychological counsellor.

Poverty,hunger and without earning money makes a man psychologically unstable which later causes in regular quarrel,domestic violence, depression, suicide and attempt to murder etc. which is a hint of a person developing psychiatric disorder. Economic self-sufficient and timely counselling may prove better result.

\section{Legal}

In some awkward situation the Administrative Authority compel to implement the Epidemic Act.,Disaster Management Act. for unruly\& antisocial personnel .Anybody violating social distancing norms \& Govt. guidelines during lockdown period committed an offence and a case under section-188\& 34 of the Indian Penal Code $54 \mathrm{~B}$ of the DDMA \& section 3 of the Epidemic Diseases Act will be initiated.

Awareness should be created among the migrants about the punishment and penalty for violation of Disaster management Act., Epidemic Act and provision of Indian Penal Code, which may preventanyone from committing any crime.

\section{SOCIAL CHALLENGES}

To control over the pandemic situation,there is no any available data of migrant workers with state Governments who are doing job in other states basing on which required No. of Buses,Trains,Planes could have been assess for movement/transportation of migrants to their native states.Both state and central Governments adopt trial and error method to deal with the situation. 
Everyday migrant workers are returning in massive scale to their states for which concerned state Govt. is facing a lot of difficulties for their accommodation in quarantine centers,arrangement of food,water,sanitation, equipment\& infrastructure facilities.Due to want of suitable building accommodation, migrants are bound to adjust in a limited space without following social distancing measures.

Everyday a lot of complains are pouring in regarding their accommodation,food, water ,sanitation, release of TikTok video in mobile causing serious problem to the organizer,administration and Govt. The migrant workers are not actually realizing the serious problem of the state,country and the world but want to enjoy their life 14 days stay in the quarantine centers like staying in star Hotel facilities.Some migrants fled away from the quarantine centers.Police personnel are searching them and filing cases against them. The relatives of the migrants are frequently coming to quarantine centers and abusing the officials of quarantine center for meeting and supplying food etc.

The very pity and misery of the migrant workers are that they are not being accepted in their own villages and family as if they are outsiders. The dead body of the migrant are not being allowed for cremation in the burial ground.The villagers and family members are afraid of spreading of corona virus.But they should not be so rigid rather more flexible.Advise them to adopt preventive measure strictly, so that corona virus will be killed or vanished.

\section{> Agriculture}

Though food is a universal necessity,those who produce it languish at the bottom of economic pyramid. The center's Prime Minister KISAN scheme provides Rs.6000 to farm family by way of cash transfer program for farmer.In India more than $70 \%$ of population depends on agriculture and it provides employment to $60 \%$ of the population.Agrarian Industry which depends on agriculture provides employment and exports commodities to different states and abroad.Due to lockdown agriculture sector affects in a very great extent. The govt. provided loan to the affected farmer to compensate their losses.If the migrant workers will be engaged in agricultural sector and cultivate in scientific way,the food grain production will be enhanced.

The govt.should supply seeds,fertilizer $\&$ pesticides to farmers timely and provide short-term loan in order to encourage farmers and increase foodgrain production of the country.

\section{$>$ Medical}

Private Medicals,Nursing Home and clinic are flourishing to provide primary health care facilities to the growing need of population and provide employment to 40 $\%$ employees in private sector.Due to lockdown for longer period, people are not going for treatment.Staffs are not getting their salary and $40 \%$ employees are thrown out job. Those Owners who have invested in Hospital Sector are unable to pay the bank installments regularly. Some private medical hospitals have been designated as covid-19 hospital for treatmentof covid-19 patient.

Concerns were raised over handling the garbage.This should be a thing to worry about, as this waste is a high potential source of infection for the human beings. Waste handlers, sanitation workers, rag pickers and even the public are at risk from handling such unmarked biohazardous waste being produced where COVID-19 patients are quarantined as well as during the screening processes in the community where the presence of asymptomatic carriers as well as infective persons is not known. No mechanism and awareness for collection and disposal of masks and medical waste generated by people under home-quarantine across the country is a matter of concern too.

This surely lead to a potential hazard to the uninfected people. Health workers, screening teams and waste handlers were not provided proper wearing kits i.e. doffing and donning procedure for PPEs was followed due to unavailability of space and resources and lack of awareness which posed a health hazard and looking into the situation where many of the health team personal were without the complete Personal Protective Equipment (PPEs) for an infection with such high transmission rates.

Adherence to the basic rules of biomedical waste segregation and management is still low in India. Discarded masks, gloves and Personal Protective Equipment (PPE) could be potential sources for the spread of this highly contagious virus. It is very critical to manage this waste as this could infect rag pickers, children or the poor living on the streets as well as the people living around and being exposed to such infections.

The Govt. should be more vigilant and take proactive measures to trace people who have had primary and secondary contact with those who tested positive.The health care workers be stationed at all check posts on road to check travelers for virus before they enter the city.Taking strict action against all those who are not revealing their travel history.

\section{Pharmaceutical}

Though there is no any coronavirus medicine,Hydroxychloroquine,paracetamol\& azithromycin used for preventive treatment.HQC is not an antiviral.It does not kill the virus only modulates the immune system.Asymptomatic frontline workers,such as surveillance workers deployed in the contentment zones and paramilitary/ police personnel involved in covid-19 related activities should take preventive medicine for their safety measures. The corona vaccine is under research stage. When efforts are going on by the scientists of the world in the field of research and experiment.We should hope and keep faith on in our scientists and researchers for early discovery of covid-19 medicines and vaccines. 


\section{Commercial}

The Trade \& Commerce inside the state,country and abroad has suffered badly on the lockdown. The imports \& export in due to stoppage of Road ,Rail \& Air transport causing huge loss to economy and foreign exchange.Goods commodities could not transported. Black marketers taking advantage, hoarding the stock, and selling the goods in high rate creating artificial shortage of goods.

Trade \& Commerce plays a vital role for supply of goods and commodities in time and maintain stability. Government has a role to check the illegal businesses and black marketers

\section{$>$ Technology}

In the new era of science and technology, all government,public and private sectors adopting latest technology in official and non-official work to get the work done in quickest means with less man power.All sort of work are being done in computer using soft wire technology.Due to lockdown the most of the company working in the information technology has been stopped and staff are left and going to their native place.

In lockdown technological sector also affected badly.Quick restoration of essential services such as technological services is prime importance otherwise general public will be deprived of getting the technological benefits.

\section{$>$ Political}

The role of political leaders and bureaucrats are very much important to make functional of state, country's machineries and command \& control over the citizens in the pandemic. The politicians should encourage the scientists to conduct research for corona vaccine and medicines. The country head will have to make constant efforts with WHO and global heads for early discovery of vaccine \& medicine for covid-19.

A clear and strong political will power is highly essential to handle the pandemic situation.

\section{Future Challeges}

The plight of migrant worker in the entire country will be a great concern of the state administration. They have lost their job due to lockdown. They will unable to feed a squire meal to their family and give proper education to theirchildren.Now it is the look out of the Govt. to arrange livelihood for those returning workers and make them selfreliant in their villages, so that they will never have to face such a crisis again. The Govt. have provided public distribution system(PDS) preventing the worst situation.To cope with the crisis transfer of cash to the bank accounts of the migrants will mitigate the suffering and compensate the loss. India's National Rural Employment Guarantee Act (NREGA) offer alternative at least for rural areas employment on demand at basic wage. The Govt. have also sanction loans without any guarantee to the migrant under the scheme of MSME Department to start small, medium and large Industries.
The migrants working and studying in oversea are facing many difficulties. They are registering on line in my government portal and requesting Indian Govt.to rescue them in the crisis. The India govt.have send Air Force, Military and Air India planes to rescue them by special plane.These migrant workers will never work in the agriculture field.There is no such factory and industry to engage them.

\section{CONCLUSION}

During lockdown, Indian economy has been disrupted and gross domestic product (GDP) has been reduced to zero percentage, which is a great concern.It will take long time for revival to previous stage.In this crisis, live and livelihood is most important to revive the economy by relaxing lockdown restriction.The Government allowed movement of buses, trains, domestic \& international flights for travelers. The public be allowed for marketing by following social distancing measures and mandatory use of facemask.Proper planning should be made to provide livelihood to migrant to make them self-reliant.The Reserve Bank of India and Finance Minister of India have declared packages in phase manner to revive economy and raise GDP to $10 \%$.The RBI has also reduced interest rate and REPO rate and directed Bank and Financial Institution to provide loan facilities for small \& medium scale Industries and six months moratorium period for loaners. The way India managed the covid-19 crisis and take step to revive economy attract the global attention.

\section{REFERENCES}

[1]. The Hindu dated.25.05.2020 page-1,6

[2]. The Hindu dated.24.05.2020 page-1,7,8

[3]. The Hindu dated 23.03.2020 page.8,9

[4]. The Hindu dated.21.03.2020

[5]. The Samaj Dated.23.05.2020.page-2

[6]. The Samaj Dated.19.05.2020 page-4

[7]. The Samaj Dated.14.05.2020 